\title{
Evaluation of the antimicrobial and antioxidant activity of 7-hydroxy-4', 6-dimethoxy-isoflavone and essential oil from Myroxylon peruiferum L.f
}

\author{
RAFAEL PEREIRA ${ }^{1}$, ANNA L. PEREIRA ${ }^{1}$, MARCILIO M. FERREIRA ${ }^{2}$, RAQUEL O.S. FONTENELLE ${ }^{2}$, \\ SILVANA SAKER-SAMPAIO ${ }^{3}$, HÉLCIO S. SANTOS ${ }^{4}$, PAULO N. BANDEIRA ${ }^{4}$, MAYRON A. \\ VASCONCELOS $^{1,5}$, JOSÉ A.N. QUEIROZ ${ }^{1}$, RAIMUNDO BRAZ-FILHO ${ }^{6}$ and EDSON H. TEIXEIRA ${ }^{1}$ \\ ${ }^{1}$ Laboratório Integrado de Biomoléculas/LIBS, Departamento de Patologia e Medicina Legal, Universidade \\ Federal do Ceará, Rua Monsenhor Furtado, s/n, Rodolfo Teófilo, 60441-750 Fortaleza, CE, Brazil \\ ${ }^{2}$ Laboratório de Microbiologia/LABMIC, Departamento de Ciências Biológicas, Universidade Estadual Vale do Acaraú, \\ Av. da Universidade, 850, Campus da Betânia, 62040-370 Sobral, CE, Brazil \\ ${ }^{3}$ Departamento de Engenharia de Pesca, Centro de Ciências Agrárias, Universidade \\ Federal do Ceará, Av. Mister Hull, 2977, 60356-001 Fortaleza, CE, Brazil \\ ${ }^{4}$ Curso de Química Orgânica, Centro de Ciências Exatas e Tecnologia, Universidade Estadual \\ Vale do Acaraú, Av. Dr. Guarani, 608, 62042-030 Sobral, CE, Brazil \\ ${ }^{5}$ Departamento de Ciências Biológicas, Faculdade de Ciências Exatas e Naturais, Universidade do Estado do Rio \\ Grande do Norte, Rua Prof. Antônio Campos, s/n, BR 110, Km 48, Costa e Silva, 59610-090 Mossoró, RN, Brazil \\ ${ }^{6}$ Laboratório de Ciências Químicas, Universidade Estadual do Norte Fluminense Darcy Ribeiro/ \\ UENF, Av. Alberto Lamego, 2000, 28013-600 Campos dos Goytacazes, RJ, Brazil
}

Manuscript received on February 28, 2018; accepted for publication on June 4, 2018

\begin{abstract}
How to cite: PEREIRA R ET AL. 2019. Evaluation of the antimicrobial and antioxidant activity of 7-hydroxy-4', 6-dimethoxy-isoflavone and essential oil from Myroxylon peruiferum L.f. An Acad Bras Cienc 91: e20180204. DOI 10.1590/0001-3765201920180204.
\end{abstract}

\begin{abstract}
This study evaluated the antibacterial, antifungal, and antioxidant effect of 7-hydroxy-4',6dimethoxy-isoflavone and essential oil of Myroxylon peruiferum. The compound was isolated and its structure elucidated by NMR. The chemical composition of essential oil determined by GC-MS analysis. To evaluation of antimicrobial activity, the Minimum Inhibitory Concentration (MIC), Minimum Bactericidal Concentration (MBC) and Minimum Fungicidal Concentration (MFC) were performed. In addition to analysis of antioxidant activity, DPPH radical scavenging tests, iron chelating assay (FIC), antioxidant reducing power assay (FRAP) and $\beta$-carotene bleaching assay (BCB) were performed. For the essential oil were identified 24 organized compounds having as main constituents; Germacrene D (17.2\%), $\alpha$-pinene (14.8\%) and E-caryophyllene (10.8\%). The results showed that isoflavone (2000 to 156 $\mu \mathrm{g} / \mathrm{mL})$ and essential oil (5.0 to $1.25 \%$ ) present antibacterial and antifungal activity against Gram-positive bacteria and filamentous fungi. The isoflavone and the essential oil also presented antioxidant activity in all the tests, mainly on inhibition of the oxidation of $\beta$-carotene test concentrations ranging from 60 to $100 \%$. In conclusion, isoflavone and essential oil from $M$. peruiferum present an antimicrobial alternative against Gram-positive bacteria, especially of the genus Staphylococcus and dermatophyte fungi of the genus Trichophyton, as well as a natural compound antioxidant.
\end{abstract}

Key words: antimicrobial activity, antioxidant activity, essential oil, isoflavone, Myroxylon peruiferum.

Correspondence to: Edson Holanda Teixeira

E-mail: edsonlec@gmail.com

ORCid: https://orcid.org/0000-0001-9564-3276 


\section{INTRODUCTION}

Plants have been used for medicinal purposes since the beginning of human civilization for prevention, treatment and cure of several diseases (De Carvalho et al. 2013). The evolution of scientific knowledge has intensified studies with medicinal plants relating their chemical composition to its effects (Cavalcante et al. 2013). In fact, several studies have investigated the presence of chemical compounds with biological potential in plant extracts and essential oils, commonly in plants used in folk medicine by communities (Guimarães et al. 2014, Dhifi et al. 2016, Jantapan et al. 2017).

The emergence of the resistant microorganisms is one of the principal public health problems of this century, increasing exponentially of the numbers of infections caused by microorganisms no longer susceptible to the common medicines used to treat them (Prestinaci et al. 2015). Studies of novel products of plant origin with antimicrobial activity have increasing interest, since emergence of resistant bacteria and fungi to conventional antimicrobials agents, aggravating this problem of global public health (Silva et al. 2012). Thus, extracts or compounds isolated from plant species used in folk medicine can be promising sources for the investigation of new antimicrobial agents (AlFatimi et al. 2007).

Bacteria that are usually involved in hospitalacquired infections include Gram-negative and Gram-positive, being Pseudomonas aeruginosa, Staphylococcus aureus and Escherichia coli the main agents (Khan et al. 2015, Horan et al. 2008). On the other hand, although the epidemiology of fungal diseases has changed over the past few decades, Candida species continue to be the main fungal pathogens responsible for most cases of severe fungal disease, such as candidiasis (Bongomin et al. 2017). While dermatophytes, such as Trichophyton rubrum, remain the most common fungal pathogens causing superficial fungal infections, especially onychomycosis, tinea pedis and tinea cruris (Silva-Rocha et al. 2017, Foster et al. 2004, Drakensjö and Chryssanthou 2011, Simonnet et al. 2011).

Myroxylon peruiferum belongs to the Fabaceae family, popularly known as "cabriúva" or "bálsamo". It is a deciduous plant, heliophytic, having about 10 to 20 meters of height. Their leaves are composed of pinnacles, occurring almost throughout the country. Their wood is suitable for furnitures, claddings and civil constructions because of its high resistance to rot (Lorenzi 1998).

Regarding popular knowledge, Lorenzi and Matos (2002) report the use of leaves, fruits and resin of M. peruiferum to for fighting wounds and ulcers. According to Lorenzi and Matos (2008), leaves, fruits and resin can be used for treating asthma, rheumatism, phlegm, external wounds, headache, torticollis and tuberculosis. França et al. (2008), in an extensive consultation on medicinal literature, states that $M$. toluifera resin is used to treat coughing caused by bronchitis. Santos et al. (1988) described that M. balsamum (L.) Harms, popularly known as "Bálsamo-to-tolú", is an effective antiseptic of the urinary tract.

Thus, the aim of this study was evaluated the antibacterial and antifungal activities on microorganism clinically relevant and the antioxidant activities of an isoflavone and essential oil isolated from the leaves of $M$. peruiferum. Moreover, the isolation of the isoflavone and the chemical profile of the essential oil was described.

\section{MATERIALS AND METHODS}

\section{PLANT MATERIAL}

Leaves and stem (1000 g of each) of M. peruiferum were collected in July 2016 at the Uruburetama massif, located in the Soledade district of Itapagé, under coordinates $03^{\circ} 37^{\prime} 86^{\prime \prime} \mathrm{S}$ and $39^{\circ} 35^{\prime} 33^{\prime \prime} \mathrm{W}$, located around $800 \mathrm{~m}$ above sea level. The plant authentication was performed and a voucher 
specimen (N. 19240) has been deposited at the herbarium Francisco José de Abreu Matos of the Universidade Estadual Vale do Acaraú (Sobral, Brazil).

\section{EXTRACTION AND ISOLATION}

Stem (1000 g), dried at room temperature, was triturated and subjected to cold extraction with ethanol for three days. The obtained solution was distilled under reduced pressure resulting in $105.5 \mathrm{~g}$ of the ethanolic extract. Then, the ethanol extract was adsorbed onto silica gel and subjected to the chromatographic column using increasing eluents: hexane, chloroform, ethyl acetate and methanol provide the following fractions: hexane (1.1 g), chloroform (19.6 g), ethyl acetate (17.5 g) and methanol (18.2 g). Chloroform fraction was subjected to silica gel column chromatography using the eluents in increasing order of polarity: hexane (100\%), hexane/chloroform (9:1, 8:2, 7:3, $6: 4,1: 1,4: 6,3: 7,2: 8,1: 9)$, chloroform (100\%), chloroform/EtOAc (9:1, 8:2, 7:3, 6:4, 1:1, 4:6, 3:7, 2:8, 1:9), EtOAc/methanol (9:1, 8:2, 7:3, 6:4, 1:1, $4: 6,3: 7,2: 8,1: 9)$ and methanol (100\%), resulting in 499 fractions with $5 \mathrm{~mL}$ each. Fractions (F'202277), resulted from extraction in chloroform/ethyl acetate $8: 2$, were grouped by similarity, yielding an off-white material of $20 \mathrm{mg}$ that was purified and analyzed.

\section{GENERAL EXPERIMENTAL PROCEDURES}

${ }^{1} \mathrm{H}$ and ${ }^{13} \mathrm{C}$ NMR where recorded on a Bruker Avance DRX-500 (500 MHz for ${ }^{1} \mathrm{H}$ and $125 \mathrm{MHz}$ for ${ }^{13} \mathrm{C}$ ); chemical shifts were given in ppm $\left({ }^{13} \mathrm{C}\right.$ and $\left.{ }^{1} \mathrm{H}\right)$. Silica gel 60 (230-400 mesh, Merck) was used for analytical TLC. Silica gel 60 (70-230 mesh, Merck) was used for column chromatography. TLC using vanillin-perchloric acid-EtOH followed by heating visualized all compounds.
EXTRACTION AND ANALYSIS OF ESSENTIAL OIL

The leaves of $M$. peruiferum was subjected to hydrodistillation in a Clevenger-type apparatus for 2 hours. At the end of the extraction, the oil volume was measured and stored in an amber glass recipient at $4{ }^{\circ} \mathrm{C}$ for analysis. The chemical composition of the essential oil was determined by gas chromatographic analysis using a mass spectrometry detector (GC-MS), model QP-2010. It was used a silica capillary column with $30 \mathrm{~m}$ in length, $0.25 \mathrm{~mm}$ i.d, $0.25 \mu \mathrm{m}$ film and helium gas with a linear velocity of $1 \mathrm{~mL} / \mathrm{min}, 250^{\circ} \mathrm{C}$ injector, $250^{\circ} \mathrm{C}$ interface and $250^{\circ} \mathrm{C}$ detector. The initial temperature was $35^{\circ} \mathrm{C}$ to $180^{\circ} \mathrm{C}$ at $4^{\circ} \mathrm{C}$ per minute, then $180^{\circ} \mathrm{C}$ to $280^{\circ} \mathrm{C}$ at $17^{\circ} \mathrm{C}$ per minute, electron impact of $70 \mathrm{eV}$.

\section{MICROORGANISMS}

In this study the following microorganism were used: the bacteria Staphylococcus aureus ATCC 25923, Staphylococcus epidermidis ATCC 12228, Escherichia coli ATCC 11303, and Pseudomonas aeruginosa ATCC 10145; the yeasts: Candida albicans ATCC 90028, Candida tropicalis LABMIC 0110, Candida parapsilosis LABMIC 0123, and Candida krusei LABMIC 0124; and the dermatophytic fungi: Trichophyton rubrum 0207 , Trichophyton rubrum 0208, Trichophyton rubrum 0209, and Trichophyton rubrum 0210.

\section{CULTURE CONDITIONS}

Bacteria were grown in Tryptone Soy Agar (TSA; Himedia, India) and incubated at $37^{\circ} \mathrm{C}$ for 24 hours. After growth, an isolated colony was removed and inoculated into $5 \mathrm{~mL}$ of Tryptic Soy Broth (TSB; Himedia, India) and incubated at $37^{\circ} \mathrm{C}$ for 18 hours. Then, the bacterial cells concentration of each inoculum was adjusted to $2 \times 10^{6}$ cells/ $\mathrm{mL}$ by turbidimetry $(620 \mathrm{~nm})$ and calibration curves previously determined for each bacterium. Fragments of Trichophyton rubrum and Candida 
spp. were transferred to tubes containing $9 \mathrm{~mL}$ of saline to obtain a turbidity equivalent to standard 5 x $10^{4} \mathrm{~mL}^{-1}$ or $0.5 \mathrm{McF}$ arland scale. The suspensions were diluted to 1:2 for Candida spp. and 1:5 for T. rubrum, both with RPMI 1640 medium with L-glutamine, without sodium bicarbonate (Sigma Chemical Co., St. Louis, Mo.), buffered to pH 7.0 with $0.165 \mathrm{M}$ morpholinepropanesulfonic acid (MOPS) (Sigma Chemical Co., St. Louis, Mo.), to obtain inoculum concentrations of approximately $2.5-5 \times 10^{3} \mathrm{CFU} / \mathrm{mL}$ for Candida spp. and $5 \times 10^{4}$ CFU/mL for T. rubrum.

\section{MINIMAL INHIBITORY CONCENTRATION (MIC)} AND MINIMUM BACTERICIDAL CONCENTRATION (MBC)

The antibacterial effect of compound isolated, and the essential oil was determined by the broth microdilution method according to the guidelines from the National Committee for Clinical Laboratory Standards, M7-A6 (NCCLS 2003), with some modifications. Earlier, the compound was diluted to $10 \mathrm{mg} / \mathrm{mL}$ in TSB medium containing 4\% dimethyl sulfoxide (DMSO) and $10 \%$ essential oil was diluted in TSB medium containing $10 \%$ Tween 20 . The concentrations of the compound were used in a ranged from 5 to 0.07 $\mathrm{mg} / \mathrm{mL}$ and the essential oil from $5.0 \%$ to $0.07 \%$. The substances were added $(100 \mu \mathrm{L})$ with bacterial suspensions previously adjusted $\left(2 \times 10^{6}\right.$ cells/ $\mathrm{mL})$. The plates were then incubated at $37^{\circ} \mathrm{C}$ for 24 hours. The minimum inhibitory concentration (MIC) was considered the lower concentration of the compound that which presents visible growth. For Minimum Bactericidal Concentration (MBC), $10 \mu \mathrm{L}$ of wells that having no visible microbial growth were inoculated onto Petri dishes with TSA medium. MBC was considered as the lower concentration capable of completely inhibiting microbial growth in plaques.
MINIMUM INHIBITORY CONCENTRATION (MIC) AND MINIMUM FUNGICIDAL CONCENTRATION (MFC)

The minimum inhibitory concentration was determined by the method described by Clinical and Laboratory Standards Institute-CLSI (CLSI M27-A2 2008), while the minimum fungicidal concentration (CFM) was according to Fontenelle et al. (2007). The compound and the essential oil were prepared in DMSO and mineral oil, respectively. $100 \mu \mathrm{L}$ of sterile RPMI 1640 was inoculated into each well of the microdilution plate followed by $100 \mu \mathrm{L}$ of sample added to the first microwell column and serially diluted until column 11; the concentration range was of 5 to $0.009 \mathrm{mg} /$ $\mathrm{mL}$. Subsequently, $100 \mu \mathrm{L}$ of the inoculum was added to all wells making a final volume of 200 $\mu \mathrm{L}$ per well. The MIC was defined by the smallest test concentration capable of inhibiting visually fungal growth. The MFC was defined by the lowest concentration which resulted in non-growth after 2 days for Candida spp. and 5 days for T. rubrum spp. after transferring $100 \mu \mathrm{L}$ solution from wells without turbidity to agar dextrose 28 (Fontenelle et al. 2007, 2008).

\section{ANTIOXIDANT ACTIVITY}

\section{Determination of DPPH radical scavenging activity}

The ability of the compound and the essential oil to scavenge the radicals DPPH was measured with reference to Duan et al. (2006). Test samples consisted of a methanolic solution containing 0.16 $\mathrm{mM}$ DPPH added to different concentrations of the isoflavone (6.25 to $400 \mu \mathrm{g} / \mathrm{mL})$ and the essential oil (2.5 to $7.8 \%)$. The control was DPPH solution without sample, and the blank consisted of sample without DPPH solution. Samples, controls and blanks were incubated in the dark at $25^{\circ} \mathrm{C}$ for 30 minutes and the optical density was measured at $517 \mathrm{~nm}$ using a microplate reader (Biochrom Asys 
UVM 340). Ascorbic acid was used as a positive control. The percentage of the DPPH radical scavenging effect was calculated by the following equation (Duan et al. 2006):

DPPH scavenging $(\%)=\left(1-\frac{\left(O . D_{\text {sample }}-O . D_{\text {blank })}\right.}{O . D_{\text {control }}}\right) \times 100 \%$

Iron chelating activity (FIC)

The iron ion chelating activity assay was performed with reference to Wang et al. (2009). The samples were prepared using deionized water to obtain concentrations equal to previous test where $2 \mathrm{mM}$ iron chloride $\left(\mathrm{FeCl}_{2}\right)$ and $5 \mathrm{mM}$ ferrozine were added. Blank and control were prepared with distilled water replacing ferrozine and samples, respectively. Samples were incubated at $25^{\circ} \mathrm{C}$ for 10 minutes and the optical density was measured at $562 \mathrm{~nm}$ using a microplate reader (Biochrom Asys UVM 340). EDTA (ethylenediamine tetraacetic acid) was used as a positive control. The FIC activity was calculated by the following equation:

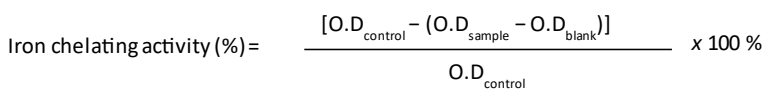

\section{Iron reduction method (FRAP)}

The antioxidant capacity of iron reduction of the sample was determined according to the method described by Ganesan et al. (2008). Initially, the isoflavone at concentrations ranging from 400 to $6.25 \mu \mathrm{g} / \mathrm{mL}$ and the essential oil from 2.5 to $7.8 \%$ were mixed with $0.2 \mathrm{M}$ sodium phosphate buffer (pH 6.6) and $1 \%$ potassium ferricyanide. Samples were incubated at $50^{\circ} \mathrm{C}$ for 20 minutes. After cooling, 10\% trichloroacetic acid was added. An aliquot was mixed with $0.1 \%$ iron hydrochloride $\left(\mathrm{FeCl}_{3}\right)$ and distilled water. After 10 minutes, the optical density of this mixed was measured at 700 nm using a microplate reader (Biochrom Asys
UVM 340). Butylhydroxyanisole (BHA) was used as a positive control. Higher the optical density, greater the compound's ability to reduce iron.

\section{Oxidation inhibition with $\beta$-carotene and linoleic} acid (BCB)

The ability of the compound and the essential oil to inhibit the oxidation of $\beta$-carotene and linoleic acid was determined by a combination of the methods described by Chew et al. (2008) and Dhongade and Chandewar (2013). In brief, the reagent for this assay consists of $3 \mathrm{~mL}$ of $0.1 \mathrm{mg} / \mathrm{mL} \beta$-carotene dissolved in chloroform, $40 \mathrm{mg}$ linoleic acid and $400 \mathrm{mg}$ Tween 40. The chloroform was evaporated using a rotary evaporator and then ultra-pure water (Milli-Q) was added to the solution. The samples were adjusted to the same concentrations as before. The optical density of the solutions was initially measured at $470 \mathrm{~nm}$ using a microplate reader (Biochrom Asys UVM 340), then again after 3 hours of incubation at $50^{\circ} \mathrm{C}$. Butylhydroxyanisole (BHA) was used as a positive control for this assay. The antioxidant activity was calculated by the following equation:

$$
\text { Antioxidant activity }(\%)=\left(\frac{O \cdot D_{\text {final }}}{O \cdot D_{\text {initial }}}\right) \times 100 \%
$$

\section{STATISTICAL ANALYSIS}

For the antioxidant assays, the percent values obtained in the DPPH, FIC and BCB assay for each of the concentrations tested were converted to absolute values, submitted to angular transformation and compared by Student's t-test for independent values. The optical density values obtained in the FRAP test were also analyzed using Student's t-test for independent values. Values of $p<0.05$ were considered statistically significant. 


\section{RESULTS AND DISCUSSION}

$\mathrm{RMN}{ }^{13} \mathrm{C}$ spectra showed 17 carbons signals, being two signals of methoxy groups. The isolated compound of the species was identified as 7-hydroxy-4',6-dimethoxy-isoflavone whose $\mathrm{RMN}{ }^{1} \mathrm{H}, \mathrm{RMN}{ }^{13} \mathrm{C}$ spectral data are according to literature values (Jha et al. 1980). This compound was isolated by Jha et al. (1980), from the desoxybenzoin obtained by condensation of phenols with derivatives of arylacetic acids or aliphatic acids. Fernandes et al. (2009) isolated the isoflavone from suspension cell cultures and callus of Dipteryx odorata, popularly known as afrormosin or castanin. The chemical structure of the isoflavone is shown in Figure 1.

The essential oil yield was $2.0 \%(\mathrm{w} / \mathrm{w})$ dry weight. The chemical composition of the volatile constituents of the essential oil of $M$. peruiferum (EOMP) and their respective percentages are set out in Table I. The results of gas chromatography coupled to mass spectrometry (CG-MS) showed the identification and quantification of 24 compounds organized by elution order in column DB-5 corresponding to $85.50 \%$ of the chemical composition of the oil, having the Germacrene D (17.2\%), $\alpha$-pinene (14.8\%) and E-caryophyllene $(10.8 \%)$ as the main. The main components (E) and (Z)-nerolidol, $\alpha$-bisabolol and (E, E)-farnesol were reported by Wanner et al. (2010).

The study of the chemical composition of $M$. peruiferum showed a predominantly presence of nerolidol and a variety of flavonoids being reported for the first time in the literature (Maranduba et al. 1979). Through the chemical analysis of the essential oil of bark and of the essential oil of trunk of M. peruiferum several phenolic substances were found. Furthermore, in its resinous fraction were found monoterpenoids, sesquiterpenoids, phenylpropanoids, alcohols and phenylpropanoids derivatives (Akisue 1971, 1972a, b, Oliveira et al. 1978, Maranduba et al. 1979).

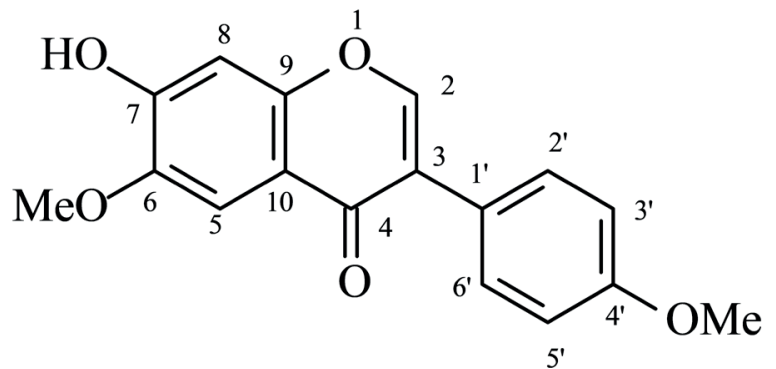

Figure 1 - Chemical structure of the 7-hydroxy-4', 6-dimethoxy-isoflavone isolated from the ethanol extract of Myroxylon peruiferum L.f bark.

TABLE I

Chemical composition of the leaves of the essential oil from Myroxylon peruiferum L.f (EOMP).

\begin{tabular}{|c|c|c|}
\hline Constituents & IK & $\%$ \\
\hline 2E-hexenol & 862 & 0.4 \\
\hline$\alpha$-tujeno & 930 & 1.5 \\
\hline$\alpha$-pinene & 939 & 14.8 \\
\hline$\beta$-pinene & 979 & 4.8 \\
\hline Mirceno & 990 & 0.1 \\
\hline$\delta$-2-carene & 1002 & 0.5 \\
\hline$\beta$-felandren & 1029 & 5.8 \\
\hline Limonene & 1029 & 2.9 \\
\hline$\gamma$-terpinene & 1059 & 0.1 \\
\hline Terpinolene & 1088 & 0.1 \\
\hline 4-terpineol & 1177 & 2.6 \\
\hline Nerol & 1229 & 0.3 \\
\hline$\alpha$-copaene & 1376 & 1.5 \\
\hline E- caryophyllene & 1419 & 10.8 \\
\hline$\gamma$-elemene & 1436 & 6.5 \\
\hline Germacrene D & 1485 & 17.1 \\
\hline$\delta$-cadinene & 1522 & 0.3 \\
\hline$\delta$-cadinene & 1523 & 2.0 \\
\hline$\alpha$-humulene & 1554 & 3.4 \\
\hline Germacrene B & 1561 & 3.5 \\
\hline Espatulenol & 1578 & 1.8 \\
\hline Oxide caryophyllene & 1583 & 1.1 \\
\hline Ledol & 1602 & 0.3 \\
\hline$\alpha$-cadinol & 1654 & 0.3 \\
\hline Total & & 85.5 \\
\hline
\end{tabular}


Variations in the chemical composition of essential oils, secondary metabolism products of plant, occur due to changes in abiotic factors as the geographic location of the plant, season and even time of day when the plants are exposed (Dudareva et al. 2004, Gobbo-Neto and Lopes 2007).

Substances like 3',4',7-trimethyl isoflavones, 6-hydroxy-4', 7-methoxy-isoflavone and germacrene $\mathrm{D}$ isolated of $M$. peruiferum leaves show antimicrobial activity against Mycobacterium tuberculosis, Mycobacterium avium and Mycobacterium kansasii (Carvalho et al. 2008). Lattanzio et al. (2009) isolated three substances from M. peruiferum stem; these were luteolin, cabreuvine and an isoflavone, described for the first time in the literature.

The results of the antibacterial activity (Table II) showed that isoflavone was able to inhibit the bacterial growth of Staphylococcus aureus ATCC 25923 and Staphylococcus epidermidis ATCC 12228 with MIC values of $2000 \mu \mathrm{g} / \mathrm{mL}$ for both strains. OEMP showed MIC at $2.5 \%$ and MBC at 5.0\% against $S$. aureus ATCC 25923 and MIC at $5.0 \%$ against $S$. epidermidis ATCC 12228, however, without MBC. The isoflavone and OEMP have not shown activity against Escherichia coli ATCC 11303 and Pseudomonas aeruginosa ATCC 10145.

Corroborating with our study, Gonçalves et al. (2005) reported that M. peruiferum L.f ethanol extract showed activity against Escherichia coli, Enterobacter aerogenes, Klebsiella pneumoniae, Providencia spp., Proteus mirabilis, Pseudomonas aeruginosa, Staphylococcus aureus, Salmonella typhimurium, Streptococcus pyogenes, Shigella

TABLE II

Antibacterial and antifungal activities of the isoflavone and essential oil from Myroxylon peruiferum L.f.

\begin{tabular}{|c|c|c|c|c|}
\hline \multirow{2}{*}{$\begin{array}{c}\text { MICROORGANISMS } \\
\text { BACTERIA }\end{array}$} & \multicolumn{2}{|c|}{ ISOFLAVONE } & \multicolumn{2}{|c|}{ ESSENTIAL OIL } \\
\hline & $\mathrm{MIC}(\mu \mathrm{g} / \mathrm{mL})$ & $\operatorname{MBC}(\mu \mathrm{g} / \mathrm{mL})$ & $\mathrm{MIC}(\%)$ & $\mathrm{MBC}(\%)$ \\
\hline Staphylococcus aureus ATCC 25923 & 2000 & N.I & 2.5 & 5.0 \\
\hline Staphylococcus epidermidis ATCC 12228 & 2000 & N.I & 5.0 & N.I \\
\hline Escherichia coli ATCC 11303 & N.I & N.I & N.I & N.I \\
\hline Pseudomonas aeruginosa ATCC 10145 & N.I & N.I & N.I & N.I \\
\hline FUNGI & $\mathrm{MIC}(\mu \mathrm{g} / \mathrm{mL})$ & $\operatorname{MFC}(\mu \mathrm{g} / \mathrm{mL})$ & $\mathrm{MIC}(\%)$ & $\mathrm{MFC}(\%)$ \\
\hline Trichophyton rubrum LABMIC 0207 & 156 & 312 & 1.25 & 2.5 \\
\hline Trichophyton rubrum LABMIC 0208 & 312 & 625 & 2.5 & 5.0 \\
\hline Trichophyton rubrum LABMIC 0209 & 625 & 1250 & 2.5 & 5.0 \\
\hline Trichophyton rubrum LABMIC 0210 & 1250 & 2500 & N.I & N.I \\
\hline Candida albicans ATCC 90028 & N.I & N.I & N.I & N.I \\
\hline Candida tropicalis LABMIC 0110 & N.I & N.I & N.I & N.I \\
\hline Candida parapsilosis LABMIC 0123 & N.I & N.I & N.I & N.I \\
\hline Candida krusei LABMIC 0124 & N.I & N.I & N.I & N.I \\
\hline
\end{tabular}

LABMIC- Microbiology Laboratory. ATCC-American Type Culture Collection. N.I - No inhibitory activity. 
flexneri and Shigella sonnei; all microorganisms obtained from clinical infections.

Matos Neto (2013) describes that the ethanol extract from $M$. peruiferum bark has antimicrobial activity against strains of Staphylococcus aureus ATCC 25923, Enterococcus faecalis ATCC 29212, Klebsiella pneumoniae, Aeromonas caviae, Pseudomonas aeruginosa, Vibrio parahaemolyticus and Escherichia coli, all pathogenic microorganisms contaminants of foods.

The isoflavone isolated from the ethyl acetate extract, the most predominant compound of the species, shows a proven antibiotic activity against Helicobacter pylori (Ohsaki et al. 1999). The ethanolic extract as well as the hexanic and chloroform fractions of the shell of M. balsamum showed activities against resistant bacteria, especially $S$. aureus resistant to methicillin and $P$. aeruginosa isolated from hospital infections, revealing their medicinal use. The bioassay with the extract identified the isoliquiritigenin calzone, an antimicrobial compound that has potential against S. aureus, S. epidermidis and S. haemolyticus (Machado et al. 2005).

Staphylococcus were more susceptible to the action of isoflavone and EOMP than Gram-negative bacteria (Table II). The difference in the susceptibly bacterial probably occurred due to structure of the cell wall in Gram-negative bacteria, composed of an external membrane, constituting a second lipid bilayer (Vaara 1992, Arunachalam et al. 2016). The intrinsic resistance of Gram-negative bacteria to many different drugs is largely attributed to the architecture of the cell envelope and multidrug efflux pumps. The outer membrane and the efflux machinery work together to reduce the intracellular concentration of various metabolites, essential oil and antibiotics so that the bacterium is able to resist the action of a range of structurally diverse compounds (Blair et al. 2015).

The results in the antifungal assays showed MIC and MFC values for the isoflavone of 156 and
$312 \mu \mathrm{g} / \mathrm{mL}$ against T. rubrum LABMIC 0207; 312 and $625 \mu \mathrm{g} / \mathrm{mL}$ against T. rubrum LABMIC 0208; 625 and $1250 \mu \mathrm{g} / \mathrm{mL}$ against T. rubrum LABMIC 0209; and 1250 and $2500 \mu \mathrm{g} / \mathrm{mL}$ against T. rubrum LABMIC 0210, respectively. The EOMP showed MIC and MFC on T. rubrum LABMIC 0207, $T$. rubrum LABMIC 0208 and T. rubrum LABMIC 0209 at concentrations ranging from 5000 to 1250 $\mu \mathrm{g} / \mathrm{mL}$ (Table II). It was observed that the EOMP did not present inhibition effectiveness against the yeast strains tested.

The isoflavonoids acquired considerable importance for exhibiting diverse biological activities like antioxidant, antifungal, bactericidal, anti-inflammatory, estrogenic and contraceptive (Jang et al. 2003). Furthermore, essential oils have been described for their antibacterial and antifungal properties, whose use may represent an advance against resistance mechanisms that inactivate standard antifungal (Castro 2010, Saad et al. 2010, Tempone et al. 2008). Thus, the discovery of natural products with antibacterial and antifungal activity may represent a new therapy through the production of phytotherapics (Khan et al. 2012, Mendes 2011, Silva et al. 2009).

Antimicrobial studies of isolated isoflavone are rarely found in literature. The isoflavone 6,7,4'-trihydroxy-isoflavone showed antibacterial activity against Bacillus cereus ATCC 11778, Listeria monocytogenes ATCC 7644, Staphylococcus aureus ATCC 29213, Staphylococcus epidermidis ATCC 12228 and Streptococcus pyogenes ATCC 19615 at concentrations of $32,128,16,32$ and $64 \mu \mathrm{g} / \mathrm{ml}$ (Hummelova et al. 2014).

The formononetine (7-hydroxy, 4'methoxyisoflavone) has several pharmacological properties such as antimicrobial, healing potential, antilipid effect, antioxidant, hyperlipidemic, cardioprotective activity, antitumor, antidiabetic and neuroprotective activity (Vishnuvathan et al. 2016). 
Zhu (2014) showed that formononetine has antifungal effects for Candida albicans Y0109 and C. albicans SC5314 with MIC values of 8 $\mu \mathrm{g} / \mathrm{mL}$. Li et al. (2012) isolated isoflavone from tobacco roots and demonstrated antibacterial effect (over 90\% inhibition) against Proteus vulgaris, Staphylococcus aureus, Escherichia coli and Bacillus subtilis.

The EOMP showed MIC and MFC of 1.25 and $2.5 \mu \mathrm{L} / \mathrm{mL}$ for C. albicans URM-6543 and C. tropicalis URM-6741, $1.25 \mu \mathrm{L} / \mathrm{mL}$ for MIC and MFC for C. glabrata URM-6393 and 0.625 and $1.25 \mu \mathrm{L} / \mathrm{mL}$ for $C$. krusei URM-6391 and $C$. parapsilosis URM- 6557 (Costa et al. 2017).

Several studies have evaluated the antibacterial and antifungal activity and reported different types of action mechanisms owing to large variety in the chemical composition of essential oils (Burt 2004, Di Pasqua et al. 2010, Greay and Hammer 2011, Qiu et al. 2011).
Certain authors consider the lipophilicity of the constituents of essential oils as a property that explains the antimicrobial activity, which allows bacterial inhibition through the permeability and depolarization of the cytoplasmic membrane. With the permeability of membrane, increase the proton evasion of cells and the modification of electrical potential of the membrane, indications of membrane damage and consequently cell death (Cowan et al. 2011, Rúa et al. 2011).

Regarding antioxidant activity, in the DPPH scavenging assay (Figures $2 \mathrm{a}$ and $3 \mathrm{a}$ ), the isoflavone and the EOMP showed antioxidant activities at all concentrations tested with percentages of approximately $60 \%$. The ascorbic acid (positive control) presented significantly higher values than the samples in all concentrations tested, with percentage values of $70-100 \%$. The ability to bind to metal ions, specifically to the iron ion (Figures $2 \mathrm{~b}$ and $3 \mathrm{~b}$ ), the compound showed dose-
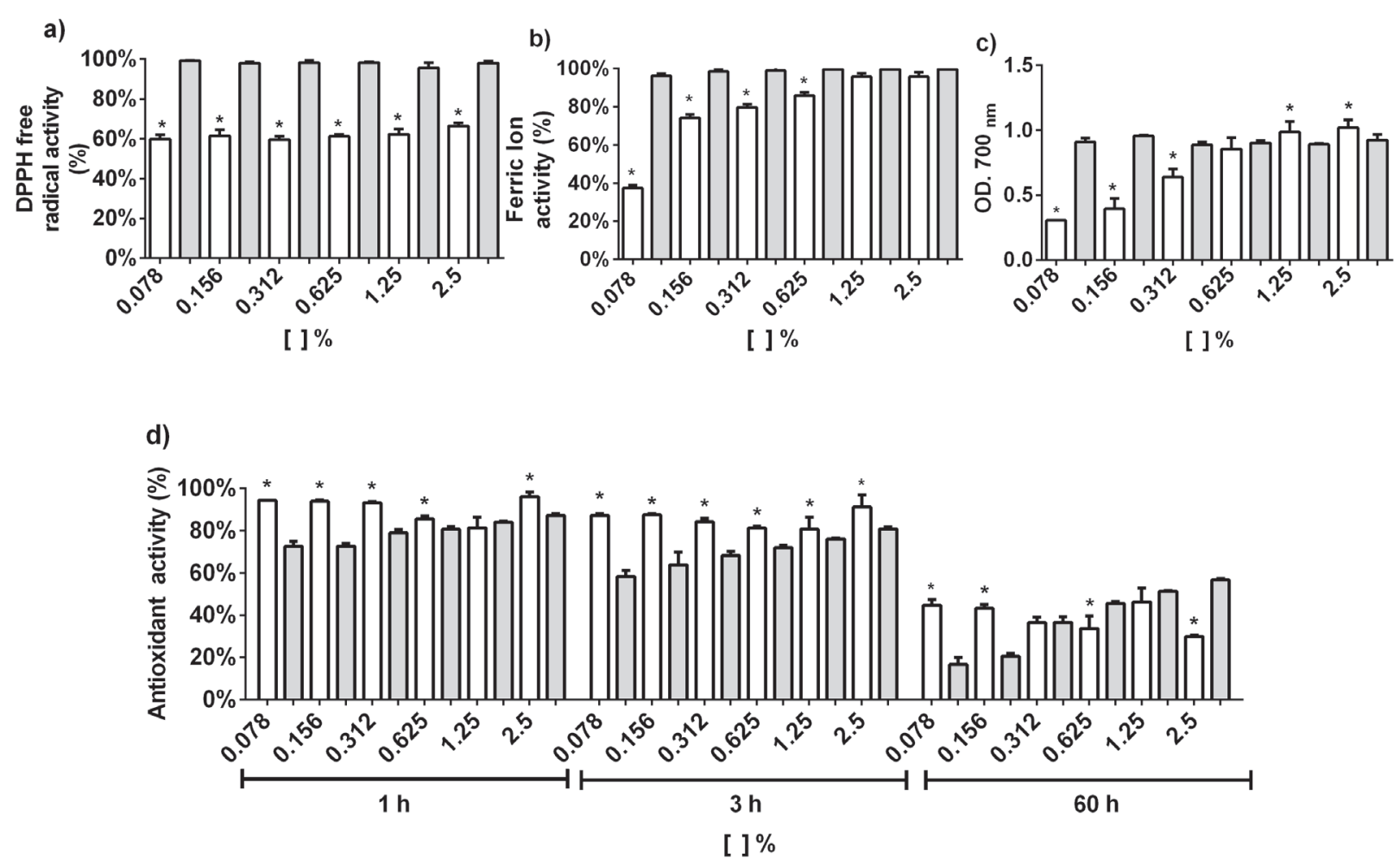

Figure 2 - Antioxidant activity of the isoflavone from Myroxylon peruiferum L.f. Test DPPH (a), FRAP (b), FIC (c) and BCB (d). White column: sample; Gray column: positive control.* Statistically significant in relation to the positive control, when $p<0.05$. 
a)

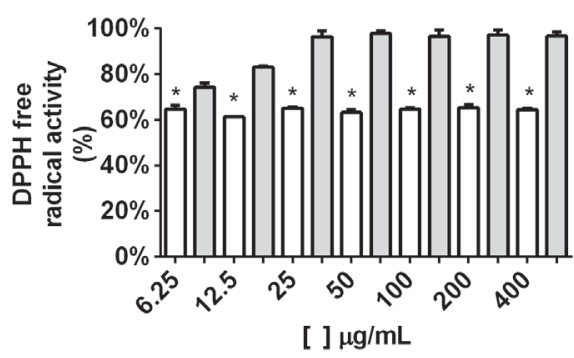

[ ] $\mu \mathrm{g} / \mathrm{mL}$ b)

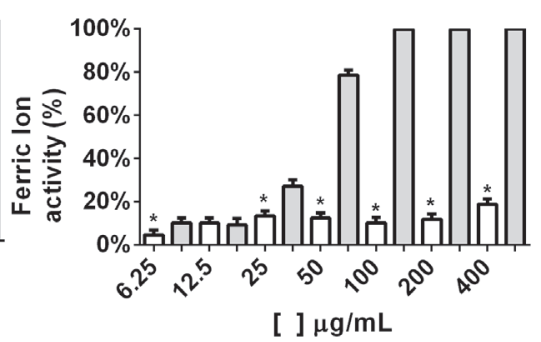

c)

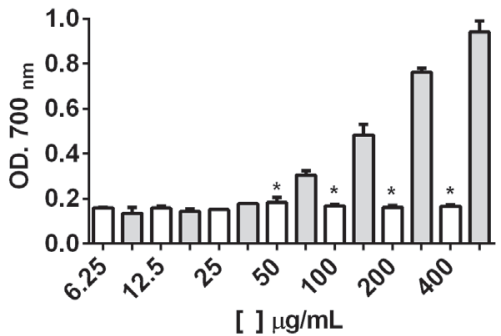

d)

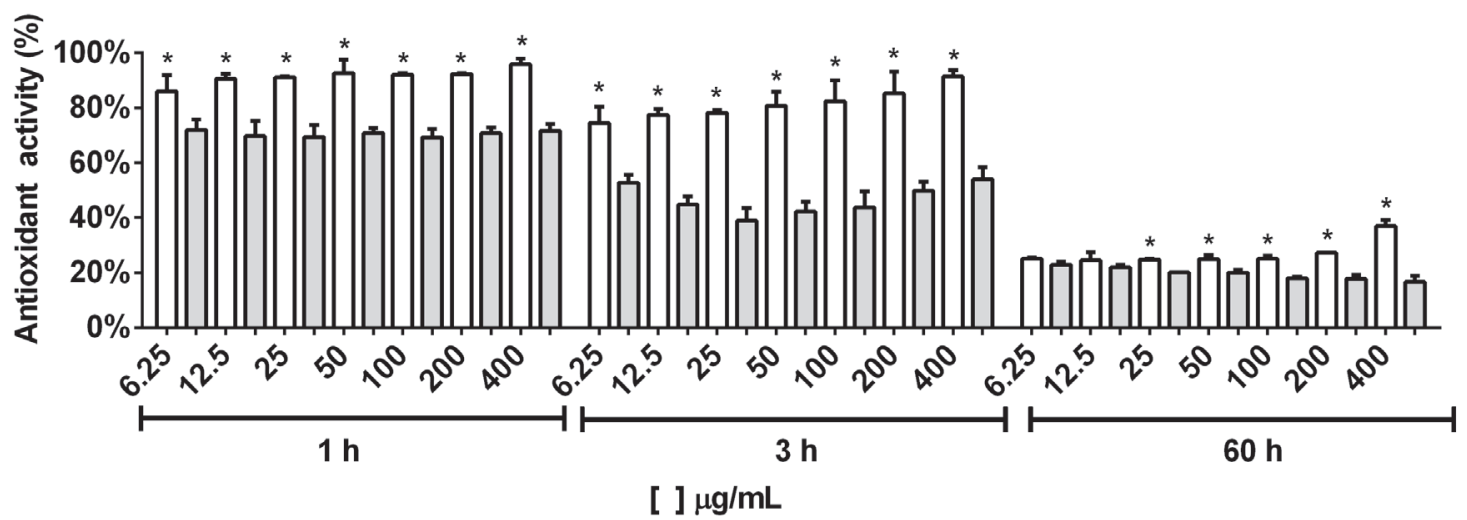

Figure 3 - Antioxidant activity of the essential oil from Myroxylon peruiferum L.f. Test DPPH (a), FRAP (b), FIC (c) and BCB (d). White column: sample; Gray column: positive control.* Statistically significant in relation to the positive control, when $p<0.05$.

dependent chelating action with percentages of 10 $20 \%$ in the concentrations of 6.25 to $400 \mu \mathrm{g} / \mathrm{mL}$, while the EOMP showed a percentage of $40-100 \%$ in concentrations of 0.078 to $2.5 \%$. The positive control (EDTA) showed values significantly from 10 to $100 \%$ when compared to compound and essential oil.

The samples were also tested for their ability to reduce $\mathrm{Fe}^{3+}$ to $\mathrm{Fe}^{2+}$. The results obtained showed that the optical density remained stable at the concentrations of isoflavone; but the optical density increased in accordance with the concentrations for the EOMP when compared to the positive control (BHA) (Figures 2c and 3c).

Finally, it was evaluated the ability of the samples to inhibit $\beta$-carotene oxidation. Both the essential oil and the isoflavone showed a high oxidizing activity in up to 60 hours of storage varying from 80 to $100 \%$ and inhibiting $\beta$-carotene oxidation in values close to these found in the positive control (BHA) (Figures 2d and 3d).

\section{CONCLUSIONS}

In this study, we have isolated the compound 7-hydroxy-4', 6-dimethoxy-isoflavone and described the chemical composition of essential oil of $M$. peruiferum. Furthermore, the isoflavone and essential oil exhibits antifungal e antibacterial, mainly on Gram-positive bacteria and dermatophytes fungi. Moreover, in the antioxidant assays the samples showed a potential antioxidant action in different trial. Thus, the essential oil and the isoflavone isolated of $M$. peruiferum can be considered as potential antimicrobial agents against infections and contaminations caused by bacteria and fungus. In addition, they can be used against oxidative stress present in infections. 


\section{ACKNOWLEDGMENTS}

The authors are grateful to the Fundação Cearense de Apoio ao Desenvolvimento Científico e Tecnológico (FUNCAP), Conselho Nacional de Desenvolvimento Científico e Tecnológico (CNPq), Coordenação de Aperfeiçoamento de Pessoal de Nível Superior (CAPES), and CENAUREM-UFC by obtaining the NMR spectra. E. H. Teixeira is a member of the Brazilian Academy of Sciences and senior investigators of CNPq. H.S. Santos, Ph.D, acknowledges financial support from the PQ-BPI/ FUNCAP (Grant\#: BP2-0107-00026.01.00/15).

\section{AUTHOR CONTRIBUTIONS}

Rafael Pereira, Anna L. Pereira, Marcilio M. Ferreira and Mayron A. Vasconcelos contributed collecting plant sample, isolation of the compound (isoflavone), essential oil extraction and antimicrobial assay. Moreover, contributed to analysis of the data and to critical reading and draft of the manuscript. Raquel O.S. Fontenelle contributed in the antimicrobial assay and to analysis of the data and to critical reading and draft of the manuscript. Silvana Saker-Sampaio contributed in the antioxidant assay and to analysis of the data and to critical reading and draft of the manuscript. Hélcio S. Santos, Paulo N. Bandeira and Raimundo Braz-Filho, contributed in the structural elucidation of the compounds by NMR, the chemical composition analysis of essential oil by GC-MS, to analysis of the data and to critical reading and draft of the manuscript. Hélcio $S$. Santos, José A.N. Queiroz and Edson H. Teixeira contributed to design the study, supervised the laboratory work and contributed to critical reading of the manuscript.

\section{REFERENCES}

AKISUE G. 1971. Secreções de Myroxylon peruiferum L.f. I Morfologia, histologia de órgãos secretores e obtenção de bálsamo. Rev Farm Bioquim Univ S Paulo 9: 115-133.
AKISUE G. 1972a. Secreções de Myroxylon peruiferum L.f. II Caracterização física do bálsamo e análise qualitativa de alguns componentes. Rev Farm Bioquim Univ S Paulo 10: 73-96.

AKISUE G. 1972b. Secreções de Myroxylon peruiferum L.f. III Caracterização física e química do óleo essencial do bálsamo e análise qualitativa de alguns componentes. Rev Farm Bioquim Univ S Paulo 10: 151-165.

AL-FATIMI M, WURSTER M, SCHRÖDER G AND LINDEQUIST U. 2007. Antioxidant, antimicrobial and cytotoxic activities of selected medicinal plants from Yemen. J Ethnopharmacol 111: 657-666.

ARUNACHALAM K, ASCÊNCIO SD, SOARES IM, AGUIAR RWS, SILVA LI, OLIVEIRA RG, BALOGUN SO AND MARTINS DTO. 2016. Gallesia integrifólia (Spreng.) Harms: In vitro and in vivo antibacterial activities and mode of action. J Ethnopharmacol 184: 128-137.

BLAIR JMA, WEBBER MA, BAYLAY AJ, OGBOLU DO AND PIDDOCK LJV. 2015. Molecular mechanisms of antibiotic resistance. Nat Rev Microbiol 13: 42-51.

BONGOMIN F, GAGO S, OLADELE RO AND DENNING DW. 2017. Global and Multi-National Prevalence of Fungal Diseases-Estimate Precision. J Fungi 3: 2-29.

BURT S. 2004. Essential oils: their antibacterial properties and potential applications in foods-a review. Int J Food Microbiol 94: 223-253.

CARVALHO TA, LATTANZIO NA, LUCARINI R, FERNANDES JB, VIEIRA PC, SILVA MFGF, MARTINS CHG AND SARRIA ALF. 2008. Potencial bactericida de extratos e substâncias isoladas de Myroxylon peruiferum (cabreúva) frente a micobactérias do trato respiratório. In: XVI Congresso de Iniciação Científica. UFSCar, Sorocaba.

CASTRO RD. 2010. Atividade antifúngica do óleo essencial de Cinnamomum zeylanicum Blume (canela) e de sua associação com antifúngicos sintéticos sobre espécies de Candida. Tese de Mestrado. Centro de Ciências da Saúde, Universidade Federal da Paraíba, Brasil, 170 p. (Unpublished).

CAVALCANTE GM, NETO JFL, BOMFIM EO AND SANTOS MF. 2013. Atividade antimicrobiana de Artocarpus heterophyllus Lam. (Moraceae) sobre o desenvolvimento de Streptococcus pneumoniae e Escherichia coli. Scientia Plena 9: 1-7.

CHEW YL, LIM YY, OMAR M AND KHOO KS. 2008. Antioxidant activity of three edible seaweeds from two areas in South East Asia. Food Sci Technol 41: 1067-1072.

COSTA MCMF ET AL. 2017. Essential oils from leaves of medicinal plants of Brazilian flora: chemical composition and activity against Candida species. Medicines 27: 1-8.

COWAN MM. 1999. Plant products as antimicrobial agents. Clin Microbiol Ver 12: 564-582. 
DE CARVALHO RBF, ALMEIDA AAC, FREITAS RM, LIMA LS, DAVID JP, DAVID JM AND FEITOSA CM. 2013. Composição química e atividade anticolinesterásica de uma fração ativa do extrato de folhas de Citrus limon (L.) Burm. Quim Nova 36: 1375-1379.

DHIFI W, BELLILI S, JAZI S, BAHLOUL N AND MNIF W. 2016. Essential Oils' Chemical Characterization and Investigation of Some Biological Activities: A Critical Review. Medicines 3: 1-16.

DHONGADE HJ AND CHANDEWAR AV. 2013. An in-vitro investigation of the antioxidant activity of Phyllanthus amarus. Int J Biomed Adv Res 4: 435-439.

DI PASQUA R, MAMONE G, FERRANTI P, ERCOLINI D AND MAURIELLO G. 2010. Changes in the proteome of Salmonella enterica serovar Thompson as stress adaptation to sublethal concentrations of thymol. Proteomics 10: 1040-1049.

DRAKENSJÖ IT AND CHRYSSANTHOU E. 2011. Epidemiology of dermatophyte infections in Stockholm, Sweden: a retrospective study from 2005-2009. Med Mycol 49(5): 484-488.

DUAN XJ, ZHANG W, LI XM AND WANG BG. 2006. Evaluation of antioxidant property of extract and fractions obtained from a red alga, Polysiphonia urceolata. Food Chem 95: 37-43.

DUDAREVA N, PICHERSKY E AND GERSHENZON J. 2004. Biochemistry of plant volatiles. Plant Physiol 135: 1893-1902.

FERNANDES RS, LOURENÇO MV, MIRANDA CES, FRANÇA SC AND JANUÁRIO AH. 2009. Validação do método de extração e quantificação de 7-hidróxi- 4',6 dimetóxi-isoflavona em culturas de células em suspensão e calos de Dipteryx odorata. Eclet Quim 34: 13-18.

FONTENELLE ROS ET AL. 2007. Chemical composition, toxicological aspects and antifungal activity of essential oil from Lippia sidoides Cham. J Antimicrob Chem 59: 934-940.

FONTENELLE ROS, MORAIS SM, BRITO ÉHS, BRILHANTE RSN, CORDEIRO RA, NASCIMENTO NRF, MENDONÇA MRK, SIDRIM JJC AND ROCHA MFG. 2008. Antifungal activity of essential oils of Croton species from the Brazilian Caatinga biome. J Appl Microbiol 104: 1383-1390.

FOSTER KW, GHANNOUM MA AND ELEWSKI BE. 2004. Epidemiologic surveillance of cutaneous fungal infection in the United States from 1999 to 2002. J Am Acad Dermatol 50(5): 748-752.

FRANÇA ISX, SOUZA JA, BAPTISTA RS AND BRITTO VRS. 2008. Medicina popular: benefícios e malefícios das plantas medicinais. Rev Bras Enferm 61: 201-208.

GANESAN P, KUMAR CS AND BHASKAR N. 2008. Antioxidant properties of methanol extract an its solvent fractions obtained from selected Indian red seaweeds. Bioresour Technol 99: 2717-2723.

GOBBO-NETO L AND NORBERTO PL. 2007. Plantas medicinais: fatores de influência no conteúdo de metabólitos secundários. Quim Nova 30: 374-381.

GONÇALVES AL, FILHO AA AND MENEZES H. 2005. Estudo comparativo da atividade antimicrobiana de extratos de algumas árvores nativas. Arq Inst Biol 72: 353358.

GREAY SJ AND HAMMER KA. 2011. Recent developments in the bioactivity of mono- and diterpenes: anticancer and antimicrobial activity. Phytochem Rev 14: 1-6.

GUIMARÃES AG, SERAFINI MR AND QUINTANSJUNIOR LJ. 2014. Terpenes and derivatives as a new perspective for pain treatment: a patent review. Expert Opin Ther Pat 24: 243-265.

HORAN TC, ANDRUS M AND DUDECK MA. 2008. CDC/ NHSN surveillance definition of health care-associated infection and criteria for specific types of infections in the acute care setting. Am J Infect Control 35: 309-332.

HUMMELOVA J, RONDEVALDOVA J, BALASTIKOVA A, LAPCIK O AND KOKOSKA L. 2014. The relationship between structure and in vitro antibacterial activity of selected isoflavones and their metabolites with special focus on antistaphylococcal effect of demethyltexasin. Lett Appl Microbiol 60: 242-247.

JANG DS ET AL. 2003. Potential cancer chemopreventive constituents of the seeds of Dipteryx odorata (tonka bean). J Nat Prod 66: 583-587.

JANTAPAN K, POAPOLATHEP A, IMSILP K, POAPOLATHEP S, TANHAN P, KUMAGAI S AND JERMNAK U. 2017. Inhibitory Effects of Thai Essential Oils on Potentially Aflatoxigenic Aspergillus parasiticus and Aspergillus flavus. Biocontrol Sci 2: 31-40.

JHA HC, ZILLIKEN F AND BREITMAIER E. 1980. Carbon-13 chemical shift assignments of chromones and isoflavones. Can J Chern 58: 1211-1219.

KHAN SMA, MALIK AAND AHMAD I. 2012. Anti-candidal activity of essential oils alone and in combination with amphotericin B or fluconazole against multi-drug resistant isolates of Candida albicans. Med Mycol 50: 33-42.

KHAN HA, AHMAD A AND MEHBOOB R. 2015. Nosocomial infections and their control strategies. Asian Pac J Trop Biomed 5(7): 509-514.

LATTANZIO NA, SARRIA ALF, TRIVELLA DBB, VIEIRA PC, FERNANDES JB, SILVA MFGF AND POLIKARPOV I. 2009. Busca de inibidores da Transtirretina (TTR) humana em extratos e substâncias isoladas de Myroxylon peruiferum (FABACEAE). Sociedade Brasileira de Química, Águas de Lindóia, São Paulo, 213 p.

LI T, GUANGYU Y, MINGMING M, JIANLIN T, YONGKUAN C AND ZHANGYU C. 2012. Isoflavonoid 
compound in tobacco rhizome and preparation and application thereof. Patent CN102351827A, filled Aug 16, 2011 issued Feb 15, 2012.

LORENZI H. 1998. Árvores brasileiras: manual de identificação e cultivo de plantas arbóreas nativas do Brasil. Nova Odessa: Plantarum.

LORENZI H AND MATOS FJA. 2008. Plantas Medicinais no Brasil: nativas e exóticas. Nova Odessa: Plantarum.

LORENZI HE AND MATOS FJA. 2002. Plantas Medicinais no Brasil: nativas e exóticas. Nova Odessa: Instituto Plantarum.

MACHADO TB, LEAL ICR, KUSTER RM, AMARAL ACF, KOKIS V, DE SILVA MG AND SANTOS KRN. 2005. Brazilian phytopharmaceuticals-evaluation against hospital bacteria. Phytother Res 19: 519-525.

MARANDUBA A, OLIVEIRA AB, OLIVEIRA GG, REIS JEP AND GOTTLIEB OR.1979. Isoflavonoids from Myroxylon peruiferum. Phytochemistry 18: 815-817.

MATOS NETO FA. 2013. Abordagem etnobotânica de plantas medicinais usadas para tratamento de lesões de pele associado, ou não, a bactérias ou fungos no município de Itapajé, Ceará, Brasil. Ceará, Brasil, 18 p.

MENDES JM. 2011. Investigação da atividade antifúngica de óleo essencial de Eugenia coryophyllata Thunb. sobre cepas de Candida tropicalis. Tese de Mestrado, Centro de Ciências da Saúde, Universidade Federal da Paraíba, Brasil, 82 p. (Unpublished).

NCCLS - NATIONAL COMMITTEE CLINICAL LABORATORY STANDARDS M27A. 2008. Reference Method for Broth Dilution Antifungal Susceptibility Testing of Yeasts: Approved Standard, M27-A3; USA: Wayne.

OHSAKI A, TAKASHIMA J, CHIBA N AND KAWAMURA M. 1999. Microanalysis of a selective potent antiHelicobacter pylori compound in a Brazilian medicinal plant, Myroxylon peruiferum and the activity of analogues. Bioorg Med Chem Lett 9: 1109-1112.

OLIVEIRA AB, IRACEMA M, MADRUGA LM AND GOTTLIEB OR. 1978. Isoflavonoids from Myroxylon balsamum. Phytochemistry 17: 593-595.

PRESTINACI F, PEZZOTTI P AND PANTOSTI A. 2015. Antimicrobial resistance: a global multifaceted phenomenon. Pathog Glob Health 109: 309-318.

QIU J ET AL. 2011. Subinhibitory concentrations of perilla oil affect the expression of secreted virulence factor genes in Staphylococcus aureus. PLoS ONE 6: 1-8..

RÚA J, FERNÁNDEZ-ÁLVAREZ L, DE CASTRO C, DEL VALLE P, DE ARRIAGA D AND GARCÍA-ARMESTO MR. 2011. Antibacterial activity against foodborne $S$. aureus and antioxidant capacity of various pure phenolic compounds. Foodborne Pathog Dis 8: 149-157.

SAAD A, FADLI M, BOUAZIZ M, BENHARREF A, MEZRIOUI NE AND HASSANI L. 2010. Anticandidal activity of the essential oils of Thymus maroccanus and Thymus broussonetii and their synergism with amphotericin B and fluconazol. Phytomedicine 17: 1057-1060.

SANTOS CAM, TORRES KR AND LEONART R. 1988. Plantas medicinais/herbarium, flora et scientia. São Paulo, Ícone.

SILVA FM, PAULA JE AND ESPINDOLA LS. 2009. Evaluation of the antifungal potential of Brazilian cerrado medicinal plants. Mycoses 52: 511-517.

SILVA MJ, ENDO LH, DIAS ALT, SILVA GA, SANTOS MH AND SILVAMA. 2012. Avaliação da atividade antioxidante e antimicrobiana dos extratos e frações orgânicas de Mimosa caesalpiniiflolia Benth. (Mimosaceae). Rev Ciên Farm Básica Apl 33: 267-274.

SILVA-ROCHA WP, DE AZEVEDO MF AND CHAVES GM. 2017. Epidemiology and fungal species distribution of superficial mycoses in Northeast Brazil. J Mycol Med 27(1): 57-64.

SIMONNET C, BERGER F AND GANTIER JC. 2011. Epidemiology of superficial fungal diseases in French Guiana: a three-year retrospective analysis. Med Mycol 49(6): 608-611.

TEMPONE AG, SARTORELLI P, TEIXEIRA D, PRADO FO, CALIXTO IA, LORENZI H AND MELHEM MS. 2008. Brazilian flora extracts as source of novel antileishmanial and antifungal compounds. Mem Inst Oswaldo Cruz 103: 443-449.

VAARA M. 1992. Agents that increase the permeability of the outer membrane. Microbiol Rev 56: 395-411.

VISHNUVATHAN VJ, LAKSHMI KS AND SRIVIDYA AR. 2016. Medicinal uses of formononetin - a review. The Journal of Ethnobiology and Traditional Medicine 126: 1197-1209.

WANG T, JÓNSDÓTTIR R AND ÓLAFSDÓTTIR G. 2009. Total phenolic compounds, radical scavenging and metal chelation of extracts from Icelandic seaweeds. Food Chem 116: $240-248$.

WANNER J, SCHMIDT E, BAIL S, JIROVETZ L, BUCHBAUER G, GOCHEV V, GIROVAT, ATANASOVA T AND STOYANOVAA. 2010. Chemical composition and antibacterial activity of selected essential oils and some of their main compounds. Nat Prod Commun 5: 1359-1364.

ZHU M. 2014. Application of 7-hydroxy-4'-methoxyisoflavone in preparation of antifungal drugs. Patent CN103565794A, filled Nov 08, 2013, issued Feb 12, 2014. 